Article - Agriculture, Agribusiness and Biotechnology

\title{
Exploitation of Heterosis among Phenotypically Diverse Capsicum Parents for Important Fruit Traits
}

\author{
Menisha Rani ${ }^{1}$ \\ https://orcid.org/0000-0002-2657-7559
}

Salesh Kumar Jindal ${ }^{* 1}$

https://orcid.org/0000-0002-0319-0327

\section{Om Prakash Meena'}

https://orcid.org/0000-0002-5093-4472

${ }^{1}$ Punjab Agricultural University, Department of Vegetable Science, Ludhiana, India.

Editor-in-Chief: Paulo Vitor Farago

Associate Editor: Adriel Ferreira da Fonseca

Received: 2020.09.15; Accepted: 2021.04.07.

*Correspondence: saleshjindal@pau.edu; Tel.: +91-83601-21290 (S.K.J.)

\section{HIGHLIGHTS}

- The effect of phenotypic distance between parental lines on the yield of $C$. annuum var. annuum $\times$ C. annuum var. grossum $\mathrm{F}_{1}$ hybrids was assessed.

- Simultaneously, the target of the research was transferring of the GMS ms10 gene from hot pepper to heat tolerant bell pepper inbreds.

- Over the BP, the hybrid MS-12 × PAU SM-31 was found to be superior in respect of total fruit yield plant $^{-1}$ and pericarp thickness.

\begin{abstract}
One nuclear male sterile (NMS) line of chilli pepper and eight elite inbred lines of bell pepper were evaluated in a line $\times$ tester mating design to project heterotic $F_{1}$ 's through studying plant growth and yield performance of developed hybrids in relation to phenotypic distance between their parental lines. Hybrids and their parental lines were grown and evaluated under poly-net house conditions at the Punjab Agricultural University, Ludhiana, India during the years 2017-2019. Pooled over the year, mean squares (MS) due to genotypes was recorded significant $(p=0.05)$ for all the traits studied, suggesting that there existed significant differences among the genotypic means that included nine parental lines and their eight $F_{1}$ hybrids. The MS due to the $G \times Y$ interaction effects were also significantly different for plant growth and fruit traits, indicating differential response of each genotype in the year. On the basis of heterotic performance, the hybrids namely MS-12 $\times$ PAU SM-31 had positive significant mid-parent heterosis (MPH) for total fruit yield plant ${ }^{-1}\left(96.68^{\star *}\right)$, number of fruits plant ${ }^{-1}\left(51.98^{* *}\right)$, pericarp thickness $\left(47.91^{* *}\right)$, fruit length $\left(25.77^{* *}\right)$, and plant height $\left(63.35^{\star *}\right)$. Apart from this cross-combination, the hybrids MS- $12 \times$ PAU SM-3 and MS-12 $\times$ PAU SM-9 also depicted MPH for total fruit yield plant ${ }^{-1}\left(71.22^{* *}\right.$ and $\left.50.64^{* \star}\right)$, fruit length $\left(41.98^{\star *}\right.$ and $\left.68.09^{\star *}\right)$ and number of fruits plant $^{-1}\left(27.60^{\star \star}\right.$ and $\left.44.73^{\star \star}\right)$. Based on better parent heterosis $(\mathrm{BPH})$, the hybrid MS-12 $\times$ PAU SM-
\end{abstract}


31 was found to be superior in respect of total fruit yield plant ${ }^{-1}\left(36.37^{\star \star}\right)$ and pericarp thickness $\left(11.27^{\star \star}\right)$. These hybrids seem to be the utmost valuable materials for the future breeding program of bell pepper.

Keywords: Bell and hot peppers; correlation analysis; heterosis; NMS; ms10 gene.

\section{INTRODUCTION}

Sweet pepper or bell pepper (Capsicum annuum var. grossum Sendt.), member of the plant genus Capsicum in the family Solanaceae, a variant of pepper, and is native to Central and South America [1]. The genus is comprises approx. 42 described species [2,3], five of which are cultivated, includes $C$. annuum L., C. chinense Jacq. (habanero types/ the hottest pepper), C. frutescens L. (tabasco pepper), C. baccatum L. Ruiz. \& Pavon (aji or peruvian pepper), and C. pubescens Ruiz. \& Pavon (rocoto pepper) [4]. The genus Capsicum has attracted the attention of pepper breeders for the collection and conservation due to their economic importance and uses [4]. The genus includes the bell and the hot peppers, which have been popular from decades and now days are of excellent commercial value, not only for the taste, shape, size and colour of the fruits [2], but also for their essential oils and the presence of capsaicin [3]. Among these five cultivated species, $C$. annuum is the most important one because it is widely grown as a vegetable or spice in both tropical and temperate area in the world [5,6]. Bell pepper is one of the most widely used vegetable with surplus weightage of offering outstanding job and income generating opportunities for huge small farmers. Bell pepper is mainly self- pollinated, but 7 to $90 \%$ of out-crossing does occur under natural habitats $[7,8]$.

Bell pepper Indian production in 2019 reached 487 thousand tonnes green fruits harvested in 34 thousand hectares. In Punjab, it is cultivated over 0.36 thousand hectare producing 5.71 thousand tonnes of bell pepper [9]. Development of high yielding hybrids with better fruit quality is pave the way to increase the bell pepper productivity per unit area as well as the farmers' income. One of the most effective tools at the breeder's disposal is appraisal of the heterotic effect of $F_{1}$ hybrid combination. The heterosis, i.e., hybrid vigor, measures the phenotypic superiority of $F_{1}$ hybrids over their parents, and it is widely used for traits such as plant growth, quality fruit production, fertility, and other adaptive traits like resistance to abiotic and biotic stresses [10]. Heterosis of bell pepper has high utilization values. In most parts of the world, hybrid seed is still produced manually using hand emasculation and pollination. This is time consuming and labour intensive, and therefore expensive. Additionally, seed purity cannot be assured owing to chance selfpollination. Use of the male sterility (MS) system in hybrid seed production can eliminate emasculation and reduces the cost of hybrid seed to the extent of $50 \%$ [11]. Hence, the research on MS has drawn a great deal of attention of domestic and international plant researchers [12]. Two types of MS, nuclear (or genic) male sterility (NMS) and cytoplasmic (or cytogenic) male sterility (CMS) have been reported and exploited to develop hybrid seed. Both NMS and CMS are available in pepper [8]. Although, CMS system has advantages over the NMS system in hybrid seed production, it has not been exploited in bell pepper due to environmental unstability and the CMS-associated ' $R f$ (the restoration of fertility) gene is scarce in bell pepper genotypes, therefore, the breeding and application of CMS system in bell pepper hybrids is limited. On the other hand, the NMS system in pepper is quite stable for MS trait and easily exploited in diverse restorers [13,14], which are a great advantage in breeding bell pepper hybrids. NMS in pepper was first reported by Martin and Crawford [15] in C. frutescens (Cayenne strain No. 4526, strain No. 69a, and strain No. 4558). Breeding hybrids with NMS lines is an important approach for the cross breeding of bell peppers. Successful utilization of heterosis with NMS system in bell pepper generally depends on the availability of locally developed NMS A- and restorer (R-) lines. Therefore, it is necessary to transfer available NMS system into local elite breeding lines. So, use of local NMS line would be helpful to develop desirable heterotic hybrids. To develop new NMS lines, we initiated breeding program in 2017 with the objective to transfer the NMS, ' $m s 10^{\prime}$ gene (originally designated as mc 509) [16] from 'MS-12', developed by Punjab Agricultural University (PAU), Ludhiana [17], to locally adapt elite bell pepper breeding lines [18]. By using NMS line MS-12, the PAU developed three commercial $\mathrm{F}_{1}$ hybrids, namely ' $\mathrm{CH}-1$ ' and ' $\mathrm{CH}-3$ ' $[19,20]$ and ' $\mathrm{CH}-27$ ' [21]. To transfer the targeted gene, the first step is generating the crosses through hybridization among the recipient and donor parent. On the other hand, intra-specific hybrids, having a new combination of gene(s), are also used in molecular studies including genome mapping [22-25]. Hence, creation of intra-species $F_{1}$ hybrids is one of the basic methods applied for extension of the genetic variability of the genus Capsicum [26].

To develop potential $F_{1}$ hybrids, the most important task for the plant breeder is the proper choice of parental lines [12]. The common approach for selecting the parents is on the basis of per se performance. The line $\times$ tester mating design is a powerful tool used by plant geneticists for preliminary evaluation of genetic 
stock for use in hybridization program with a view to identify good general and specific combiners. It can evaluate relatively more number of genotype or lines at a time than diallel and partial diallel crosses. The heterotic studies are provides the basis for exploitation of valuable hybrid combinations and their commercial utilization in future breeding programs. The main objective of the present study was to assess the extent of heterosis in desirable direction and to project heterotic $F_{1}$ hybrids by studying plant growth and yield performance of hybrids in relation to phenotypic distance between their parental lines. Another goal was to analyze genotype correlations among fruit traits over the years.

\section{MATERIAL AND METHODS}

\section{Research location and genetic materials}

The study was carried out between October, 2016 to June, 2019 at the Vegetable Research Farm, Punjab Agricultural University (PAU), Ludhiana, India. The Farm is located at $30^{\circ} 54^{\prime} \mathrm{N}, 75^{\circ} 51^{\prime}$ E, and $252 \mathrm{~m}$ above sea level. The plant materials for the study consisted of one NMS lines namely, 'MS-12' of chilli pepper, developed by PAU, Ludhiana, and eight genetically diverse elite breeding lines (selected based on their previously observed horticultural traits) of bell pepper, originated from various sources, and their major characteristics are described in Table 1.

Table 1. Details of parental lines of chilli and bell peppers used for hybridization in the present study

\begin{tabular}{|c|c|c|c|c|c|c|c|}
\hline Parental lines & Fertility status & $\begin{array}{l}\text { Fruit } \\
\text { colour }\end{array}$ & $\begin{array}{l}\text { Fruit } \\
\text { orientation }\end{array}$ & $\begin{array}{l}\text { Fruit } \\
\text { shape }\end{array}$ & $\begin{array}{l}\text { Number of } \\
\text { lobes fruit }\end{array}$ & Pungency levels & Sourcet \\
\hline MS-12 & $\begin{array}{l}\text { Nuclear male } \\
\text { sterile } \\
\text { (ms10ms10) }\end{array}$ & $\begin{array}{l}\text { Light } \\
\text { green }\end{array}$ & Erect & Elongate & 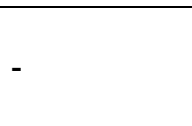 & Highly pungent & $P^{\prime} A U^{a}$ \\
\hline PAU SM-1 & Male fertile & Green & Pendent & Blocky & Three & Non-pungent & PAU \\
\hline PAU SM-2 & Male fertile & Green & Pendent & Blocky & Three & Non-pungent & PAU \\
\hline PAU SM-3 & Male fertile & Green & Pendent & Blocky & Three & Non-pungent & PAU \\
\hline PAU SM-4 & Male fertile & Green & Pendent & Blocky & Four & Non-pungent & PAU \\
\hline PAU SM-9 & Male fertile & Green & Erect & Blocky & Four & Non-pungent & PAU \\
\hline PAU SM-17 & Male fertile & Green & Pendent & Blocky & Two & Non-pungent & PAU \\
\hline PAU SM-21 & Male fertile & Green & Pendent & Blocky & Three & Non-pungent & PAU \\
\hline PAU SM-31 & Male fertile & $\begin{array}{l}\text { Cream to } \\
\text { light green }\end{array}$ & Pendent & Elongate & - & Non-pungent & PAU \\
\hline
\end{tabular}

†aPAU: Punjab Agricultural University, Ludhiana, India

\section{Development of $F_{1}$ 's and their evaluation}

Seeds of eight $F_{1}$ hybrids were developed through manual pollination by involving one NMS line and eight elite breeding lines as testers following line $\times$ tester mating design. The true selfed seeds of parental lines were sown in well-prepared nursery bed of $0.15 \mathrm{~m}$ height and $1.0 \mathrm{~m}$ wide. Seed treated with Captaf $50 \%$ WP (Rallis India Ltd, Mumbai, India) @ 2-3 g. $\mathrm{kg}^{-1}$ of seed were sown on 15 ${ }^{\text {th }}$ October, 2016 at a depth of $1-2 \mathrm{~cm}$. Seedlings were hardened by withholding water 5 days before transplanting. The seedlings were transplanted in the polyhouse on $13^{\text {th }}$ November, 2016. Eight $F_{1}$ hybrid combinations were developed by manually pollinating one NMS line with eight testers. Between $9 \mathrm{AM}-11.30 \mathrm{AM}$, the freshly fully opened flowers of NMS line (female line) were selected and pollinated with the pollen collected from the freshly opened male parent flowers. The petals of the pollen-source flower was removed, so that, the staminal columns and anthers were uncovered. To transfer pollen, anthers of the male parent were taken and gently touched on tip of the stigmatic surface of the female flowers. The pollinated flowers were tagged. The mature red ripe crossed fruits were harvested, and the $F_{1}$ seeds were extracted individually from each cross.

In 2017-18 and 2018-19, total eight $F_{1}$ hybrids were evaluated along with their nine parents (one NMS line and eight testers) and one check hybrid namely 'Indra' (marketed by Syngenta Seeds Pvt Ltd in India) under poly-house conditions. The first year sowing was done on $03^{\text {rd }}$ October, 2017 and transplanted on $10^{\text {th }}$ November, 2017, and the second year sowing on $25^{\text {th }}$ September, 2018 and transplanted on $05^{\text {th }}$ November, 2018. The seedlings were planted on beds, which were mulched with black polythene sheet, spaced $90 \mathrm{~cm}$ (between beds) $\times 30 \mathrm{~cm}$ (within bed). In both years, the experiments were laid out in a randomized complete block design (RCBD) with three replications. Each replicate comprised a single row of nine plants. The cultivation protocol ensured optimal growing conditions throughout the crop season, applying the standard recommended dose of fertilizer (125 kg nitrogen, $75 \mathrm{~kg}$ phosphorus and $65 \mathrm{~kg}$ potash per hectare), irrigation 
(using drip irrigation system), weeding, canopy training and pruning. Special attention was given to the checkout of insect-pests and diseases under polyhouse condition [27]. During the crop cultivation, fertilization was regularly applied in a form of foliar spraying with $3 \mathrm{~g} \cdot \mathrm{L}^{-1}$ of water soluble fertilizer containing N:P:K 19:19:19 (IFFCO- Indian Farmers Fertiliser Cooperative Limited, New Delhi, India).

\section{Observations recorded}

The data were recorded on the following traits from five randomly selected plants excluding the two border plants, one on each side. Seven traits including plant height $(\mathrm{cm})(\mathrm{PH})$, fruit weight $(\mathrm{g})(\mathrm{FW})$, fruit length $(\mathrm{cm})(\mathrm{FL})$, fruit width $(\mathrm{cm})(\mathrm{FWT})$, pericarp thickness $(\mathrm{mm})(\mathrm{PT})$, number of fruits plant $^{-1}(\mathrm{NFP})$ and total fruit yield plant ${ }^{-1}(\mathrm{~g})(\mathrm{TYP})$ were recorded.

\section{Statistical analysis}

Combined and single year analyses of variance were performed for each variable by the software Analysis of Genetic Design using R Version 5.0 (AGD-R). Pearson's linear correlation coefficients ( $r$ ) were estimated to determine the relation between growth and fruit traits using the $R$ software packages version 3.5.1 in Rstudio 1.1.456 [28] and testing of significance at $p<0.05, p<0.01$ and $p<0.001$. The magnitude of heterosis was estimated in relation to mid-parent, better parent and standard check hybrids values [29].

\section{RESULTS AND DISCUSSION}

\section{Analysis of variance for experimental design}

The estimation of mean squares (MS) due to genotypes over the years were highly significant $(p=0.05)$ for all studied characters, suggesting that there existed true significant differences among the genotypic means that included nine parental lines and their eight $F_{1}$ hybrids. The pooled ANOVA showed that the MS due to years were non-significant for all the traits except number of fruits plant ${ }^{-1}$, this suggested that the environmental conditions of both the years were same. However, the MS due to the $G \times Y$ interaction effects were significant for plant growth and fruit traits, indicating that differential response of each genotype in the year. The magnitude of MS attributed to the genotypes was much higher than the MS due to environments and the $G \times E$ interaction effects for all the traits. Earlier research study in which fruit traits were estimated have showed significant genetic variations among the progenies [10,30-32].

Table 2. Analysis of variance for the experimental design for plant growth and yield parameters in bell pepper over the years

\begin{tabular}{|c|c|c|c|c|c|c|c|c|}
\hline Source of variance & $d f$ & $\begin{array}{l}\text { Plant } \\
\text { height }(\mathrm{cm})\end{array}$ & $\begin{array}{l}\text { Fruit } \\
\text { weight } \\
\text { (g) }\end{array}$ & $\begin{array}{l}\text { Fruit } \\
\text { length } \\
(\mathrm{cm})\end{array}$ & $\begin{array}{l}\text { Fruit } \\
\text { width } \\
(\mathrm{cm}) \\
\end{array}$ & $\begin{array}{l}\text { Pericarp } \\
\text { thickness } \\
(\mathrm{mm})\end{array}$ & $\begin{array}{l}\text { Number of } \\
\text { fruits plant }^{-1}\end{array}$ & $\begin{array}{l}\text { Total fruit } \\
\text { yield plant } \\
{ }^{1}(\mathrm{~g})\end{array}$ \\
\hline Replication & 2 & 221.58 & 6.18 & 0.24 & 0.01 & 0.07 & 120.34 & 33680.60 \\
\hline Genotype & 16 & $17902.24^{*}$ & $4985.02^{*}$ & $12.09^{*}$ & $21.35^{\star}$ & $7.77^{*}$ & $25598.11^{*}$ & $\begin{array}{l}1185007.2 \\
0^{*}\end{array}$ \\
\hline Year & 1 & $790.08^{\text {ns }}$ & $3.48^{\text {ns }}$ & $0.10^{\text {ns }}$ & $0.025^{\mathrm{ns}}$ & $0.04^{\mathrm{ns}}$ & $906.13^{*}$ & $966.60^{\text {ns }}$ \\
\hline Genotype $\times$ Year & 16 & $572.02^{*}$ & $63.93^{*}$ & $0.91^{*}$ & $0.42^{*}$ & $0.18^{*}$ & $340.35^{\star}$ & $64947.48^{*}$ \\
\hline Pooled error & 64 & 218.62 & 19.97 & 0.33 & 0.10 & 0.07 & 134.25 & 17532.03 \\
\hline
\end{tabular}

Data's are mean sums of squares; *significant at $p=0.05$; ns: non-significant at $5 \%$ level of significance

\section{Horticultural performance of parental lines and testcrosses}

Mean performance of parental lines and test crosses for plant growth and fruit traits for the two years and pooled over the years are summarized in Table 3 and 4, respectively. In bell pepper, plant height is one of the eminently pivotal traits from productivity and crop management view point [33]. The parental line PAU SM-21 recorded minimum plant height in $Y 1(48.80 \mathrm{~cm}), \mathrm{Y} 2(60.51 \mathrm{~cm})$ and over the years $(54.66 \mathrm{~cm})$. The maximum plant height was recorded by MS-12 with the mean of $169.90 \mathrm{~cm}$ in $Y 1,181.40 \mathrm{~cm}$ in $Y 2$, and $175.65 \mathrm{~cm}$ when pooled over the years. The plant height of $F_{1}$ hybrids ranged from $113.44 \mathrm{~cm}$ in MS-12 $\times$ PAU SM-21 to $226.20 \mathrm{~cm}$ in MS-12 x PAU SM-31 under Y1, from $98.13 \mathrm{~cm}$ in MS-12 × PAU SM-21 to 207.57 $\mathrm{cm}$ in MS-12 $\times$ PAU SM-17 under Y2, and from $105.79 \mathrm{~cm}$ in MS-12 $\times$ PAU SM-21 to $212.98 \mathrm{~cm}$ in MS-12 $\times$ PAU SM-31 over the years. These results are inconsistent with findings of other researchers on $C$. annuum, Meena and coauthors [10] observed plant height of hybrids varied from 56.30 to $104.24 \mathrm{~cm}$ across the environments. 
For fruit weight, the mean values of parental lines varied from $3.89 \mathrm{~g}$ (MS-12) to $89.40 \mathrm{~g}$ (PAU SM-3) in Y1, from $3.24 \mathrm{~g}$ (MS-12) to $85.27 \mathrm{~g}$ (PAU SM-4) in Y2, and from $3.57 \mathrm{~g}$ (MS-12) to $83.81 \mathrm{~g}$ (PAU SM-3) over the two years. On the contrary, the mean performance of the $F_{1}$ hybrids ranged from $9.17 \mathrm{~g}$ to $16.46 \mathrm{~g}$ in $\mathrm{Y} 1$, from $8.01 \mathrm{~g}$ to $15.84 \mathrm{~g}$ in $\mathrm{Y} 2$, and $8.59 \mathrm{~g}$ to $15.35 \mathrm{~g}$ across the years. The $\mathrm{F}_{1}$ hybrid MS-12 $\times$ PAU SM-3 depicted highest mean value for fruit weight in Y1, MS-12 × PAU SM-1 in Y2, and MS-12 × PAU SM-3 when means were pooled across the years. The ranges of mean values for fruit length were $4.69 \mathrm{~cm}(\mathrm{MS}-12)$ to $7.81 \mathrm{~cm}$ (PAU SM-4) with a mean of $6.03 \mathrm{~cm}$ in Y1; $4.14 \mathrm{~cm}$ (MS-12) to $7.76 \mathrm{~cm}$ (PAU SM-31) with an average of $6.01 \mathrm{~cm}$ in Y2, and $4.42 \mathrm{~cm}$ (MS-12) to $7.41 \mathrm{~cm}$ (PAU SM-4) with over all mean of $6.02 \mathrm{~cm}$ when pooled over the years for parental lines in contrast to $6.02 \mathrm{~cm}$ (MS-12 $\times$ PAU SM-4) to $10.52 \mathrm{~cm}$ (MS-12 $\times$ PAU SM1) with an average of $7.64 \mathrm{~cm}$ in $\mathrm{Y} 1 ; 5.28 \mathrm{~cm}$ (MS-12 $\times$ PAU SM-4) to $9.15 \mathrm{~cm}(\mathrm{MS}-12 \times \mathrm{PAU}$ SM-1) with a mean of $7.53 \mathrm{~cm}$ in $\mathrm{Y} 2$, and $5.65 \mathrm{~cm}$ (MS-12 $\times$ PAU SM-4) to $9.84 \mathrm{~cm}$ (MS-12 $\times$ PAU SM-1) with an overall mean of $7.58 \mathrm{~cm}$ over the years for $F_{1}$ hybrids. This range corroborates with results of other workers [34] who found length of the fruit from $2.2 \mathrm{~cm}$ to $16.2 \mathrm{~cm}$.

Among the parental lines, MS-12 recorded the minimum fruit width in $Y 1, Y 2$, and over the two years with mean values of $1.30 \mathrm{~cm}, 1.47 \mathrm{~cm}$, and $1.39 \mathrm{~cm}$, respectively while the maximum was observed in PAU SM-4 with an average of $7.66 \mathrm{~cm}$ in $\mathrm{Y} 1,6.96 \mathrm{~cm}$ in $\mathrm{Y} 2$, and $7.31 \mathrm{~cm}$ across the years. Mean performance of the $F_{1}$ hybrids ranged from $1.62 \mathrm{~cm}$ in MS-12 $\times$ PAU SM-31 to $2.70 \mathrm{~cm}$ in MS-12 $\times$ PAU SM-3 under Y1, from $1.52 \mathrm{~cm}$ in MS-12 $\times$ PAU SM-17 to $2.96 \mathrm{~cm}$ in MS-12 $\times$ PAU SM-21 under Y2, and $1.66 \mathrm{~cm}$ in MS-12 $\times$ PAU SM-17 to $2.73 \mathrm{~cm}$ in MS-12 $\times$ PAU SM-21 over the years. The pericarp thickness of parental lines varied from $0.78 \mathrm{~mm}$ (MS-12) to $4.90 \mathrm{~mm}$ (PAU SM-3) in Y1, from $0.90 \mathrm{~mm}$ (MS-12) to $4.48 \mathrm{~mm}$ (PAU SM-4) in Y2, and from $0.84 \mathrm{~mm}$ (MS-12) to $4.60 \mathrm{~mm}$ (PAU SM-3) across the years. The mean performance of $F_{1}$ hybrids ranged from $1.45 \mathrm{~mm}$ (MS-12 × PAU SM-17) to $2.50 \mathrm{~mm}$ (MS-12 × PAU SM-21) in Y1, from $1.69 \mathrm{~mm}$ (MS$12 \times$ PAU SM-17) to $2.21 \mathrm{~mm}$ (MS-12 $\times$ PAU SM-2) in Y2, and from $1.57 \mathrm{~mm}$ (MS-12 $\times$ PAU SM-17) to 2.35 $\mathrm{mm}$ (MS-12 $\times$ PAU SM-21) across the years. Higher traits' mean (fruit width and pericarp thickness) of cross MS-12 $\times$ PAU SM-21 over the years indicate the presence of genes that enhances traits' phenotype and hence maximizing the chances of recovering superior recombinant inbred lines (RILs) in advanced generations.

The number of fruits plant ${ }^{-1}$ produced by parental lines varied from 23.25 (PAU SM-2) to 223.15 (MS-12) in Y1, from 24.52 (PAU SM-4) to 187.83 (MS-12) in Y2, and from 25.57 (PAU SM-2) to 205.49 (MS-12) across the two years. On the contrary, the mean performance of the $F_{1}$ hybrids ranged from 90.68 to 232.03 under Y1, from 105.49 to 199.35 under Y2, and from 98.88 to 215.69 across the years. The hybrid MS-12 $\times$ PAU SM-31 expressed the highest mean values for number of fruits plant $^{-1}$ in $\mathrm{Y} 1, \mathrm{Y} 2$ and pooled over the years. The range of mean values of parental lines for total fruit yield plant ${ }^{-1}$ was $479.21 \mathrm{~g}$ in MS-12 to $2021.24 \mathrm{~g}$ in PAU SM-4 under Y1, $399.19 \mathrm{~g}$ in MS-12 to $2167.81 \mathrm{~g}$ in PAU SM-3 under Y2, and $439.20 \mathrm{~g}$ in MS-12 to $2007.29 \mathrm{~g}$ in PAU SM-3 when means were polled over the years. Ranges in mean value of $F_{1}$ hybrids were $704.06 \mathrm{~g}$ to $2270.63 \mathrm{~g}$ with an average of $1422.73 \mathrm{~g}$ in $\mathrm{Y} 1,855.62 \mathrm{~g}$ to $1921.19 \mathrm{~g}$ with a mean value of $1407.81 \mathrm{~g}$ in $\mathrm{Y} 2$, and $779.84 \mathrm{~g}$ to $2095.91 \mathrm{~g}$ with an overall mean of $1415.27 \mathrm{~g}$ when pooled over the years. The highest and the lowest mean values for total fruit yield plant ${ }^{-1}$ were recorded by the $\mathrm{F}_{1}$ hybrids MS-12 $\times$ PAU SM-3 and MS-12 $\times$ PAU SM-17, respectively under Y1, Y2 and across the years. Fruit yield plant ${ }^{-1}$ of $^{2}$ tested hybrids of bell pepper in Korea ranged from $1194.0 \mathrm{~g}$ to $2907.0 \mathrm{~g}$ [35]. Matsunaga and coauthors [36] suggested that an inbred 'Sweet Pepper Parental Line Nou-1' has been used as a seed parent for $F_{1}$ hybrids of bell pepper. In a study, Sood and Kumar [37] had observed the range of fruit yield plant ${ }^{-1}$ from $172.66 \mathrm{~g}$ to $359.33 \mathrm{~g}$, and fruit length from $4.42 \mathrm{~cm}$ to $10.11 \mathrm{~cm}$, and reported that the lines 'EC-464107', 'EC-464115', and 'Kandaghat Selection' were promising parents.

\section{Expression of heterosis for plant growth and fruit traits}

Hybrid breeding bestows an opportunity to raise the productivity of bell pepper. The major goal of heterosis in any crop is to accomplish high yield potential and better quality. Hybrids are becoming popular in many crops as they give an opportunity to utilize the synergistic effect of a genetic combination [12]. To a systematic breeding program, it is essential to identify the parental lines as well as crosses to bring genetic improvement in economic traits. The magnitude of heterosis depends on the genetic and phenotypic diversity existing between the parental lines [10].

The heterosis \% values relative to mid-parents $(\mathrm{MPH})$, better parents $(\mathrm{BPH})$, and standard check $(\mathrm{SCH})$ are presented in Table 5. Normally, the MPH values were higher than the BPH values for all the studied traits. All the cross-combinations expressed a varied degree of heterosis for plant growth and fruit traits. In the present research, some $F_{1}$ hybrids exhibited higher positive $\mathrm{MPH}, \mathrm{BPH}$ and $\mathrm{SCH}$, whereas some $\mathrm{F}_{1}$ hybrids 
manifested low positive or negative heterosis. This is mainly due to the varying extent of genetic diversity between the parental lines of different crosses for plant growth and fruit traits. For plant height, the MPH, $\mathrm{BPH}$ and $\mathrm{SCH}$ varied from 3.74 to $83.95 \%$, from -33.23 to $33.14 \%$ and from -0.99 to $97.44 \%$ for the hybrid MS-12 × PAU SM-21 and MS-12 x PAU SM-31 in Y1, from -18.87 (MS-12 × PAU SM-21) to 53.66\% (MS-12 $\times$ PAU SM-2), from -45.90 (MS-12 $\times$ PAU SM-21) to $14.43 \%$ (MS-12 $\times$ PAU SM-17) and -0.31 (MS-12 $\times$ PAU SM-21) to $110.86 \%$ (MS-12 $\times$ PAU SM-17) in Y2, and from -8.14 (MS-12 × PAU SM-21) to 63.35\% (MS-12 $\times$ PAU SM-31), from -39.77 (MS-12 × PAU SM-21) to 21.25\% (MS-12 × PAU SM-31), -0.68 (MS-12 × PAU SM-21) to $99.97 \%$ (MS-12 $\times$ PAU SM-3) pooled over the years. Of the eight hybrids evaluated, six hybrids in $\mathrm{Y} 1$, four in $\mathrm{Y} 2$ and six when pooled across the years depicted significant heterosis over mid-parent, whereas six hybrids in each Y1, Y2 and across the years expressed significant positive heterosis over standard check Indra. Smaller plant stature is positively related to early fruit setting in bell pepper. On the basis of per se performance and BPH the hybrids MS-12 $\times$ PAU SM-21 was identified along with smaller plant height in $\mathrm{Y} 1$, the hybrids MS-12 $\times$ PAU SM-9 and MS-12 $\times$ PAU SM-21 in Y2 and across the years. Meena and coauthors [10], Nsabiyera and coauthors [34], Nascimento and coauthors [38] also reported that hybrid breeding is the best strategy for obtaining bell pepper inbred lines suitable for pot culture under net-house conditions. None of the hybrids was superior to the mid-parent, better parent and standard check for fruit weight and fruit width. In present study, for these traits, the low heterosis was recorded for all the developed hybrids due to the higher contribution of maternal parent 'MS-12' (chilli pepper) in the expression of these trait as compared to testers (bell pepper) in the first cycle of crossing.

Fruit length is of the utmost importance in chilli that is destined for fresh consumption. For fruit length, the hybrid MS-12 $\times$ PAU SM-1 expressed the highest MPH value of $93.86 \%$ as well as the maximum $\mathrm{BPH}$ and $\mathrm{SCH}$ values of $70.74 \%$ and $25.23 \%$, respectively in $\mathrm{Y} 1$; the hybrid MS-12 $\times$ PAU SM-17 depicted maximum significant positive MPH and BPH values of 72.12 and $70.29 \%$, while the hybrid MS-12 $\times$ PAU SM1 showed maximum SCH value of $19.77 \%$ in Y2, and the hybrid combinations MS-12 $\times$ PAU SM-1 had highest MPH and SCH values of 78.74 and $22.63 \%$ whereas MS-12 $\times$ PAU SM-9 had BPH value of $58.51 \%$ when pooled across the years. Out of eight hybrids, seven and one in $\mathrm{Y} 1$, six and two in $\mathrm{Y} 2$ and six and one across the year exhibited significantly positive and negative $\mathrm{BPH}$, respectively. Over the standard check, one and six in $\mathrm{Y} 1$, three and four in $\mathrm{Y} 2$ and two and six over the years expressed significant positive and negative heterosis, respectively.

For pericarp thickness, the magnitude of heterosis over MP and BP ranged from -31.01 (MS-12 $\times$ PAU SM-17) to $43.66 \%$ (MS-12 $\times$ PAU SM-31) and -57.63 (MS-12 $\times$ PAU SM-17) to $7.37 \%$ (MS-12 $\times$ PAU SM31) in Y1, from -27.80 (MS-12 $\times$ PAU SM-1) to $51.69 \%$ (MS-12 $\times$ PAU SM-31) and -56.42 (MS-12 $\times$ PAU SM-1) to $14.77 \%$ (MS-12 $\times$ PAU SM-31) in Y2, and from -24.63 (MS-12 × PAU SM-17) to 47.91\% (MS-12 $\times$ PAU SM-31) and -53.90 (MS-12 × PAU SM-4) to 11.27\% (MS-12 $\times$ PAU SM-31) across the years. Moreover, none of the $F_{1}$ hybrids expressed significant positive $\mathrm{SCH}$ for pericarp thickness. According to Klieber [39] and Lannes and coauthors [40] the smaller fruits with thin pericarp are more suitable for the processing industry, since they contain more dry matter content and soluble solids than large fruited genotypes. Higher content of dry matter means higher processed product yield. From this research (across the year), over the standard check 'Indra', the hybrids namely, MS-12 × PAU SM-4 and MS-12 × PAU SM-2 were identified with mildly pungent (data not shown) small fruits and had thin pericarp, suitable for processing into less pungent pepper powder. On the contrary, the hybrids, MS-12 $\times$ PAU SM-17, MS-12 $\times$ PAU SM-21, MS-12 $\times$ PAU SM31 and MS-12 $\times$ PAU SM-9 were identified as promising to develop hot chilli cultivars with small fruit size, and could be useful for processing into pungent pepper powder production.

The number of fruits plant $^{-1}$ is the most important chief component of total fruit yield in Capsicum. Heterosis for fruit yield has principally been attributed to heterosis for number of fruits plant ${ }^{-1}$. In respect to number of fruits plant ${ }^{-1}$, the range of heterosis over MP, BP and SH varied from -29.60 to $50.40 \%,-59.36$ to $3.98 \%$ and 191.84 to $646.71 \%$, respectively under $Y 1$, from -1.79 to $53.86 \%,-43.83$ to $6.13 \%$, and 336.64 to $725.11 \%$ under $\mathrm{Y} 2$, and from -16.83 to $51.98 \%,-51.88$ to $4.96 \%$ and 258.04 to $681.00 \%$ when pooled across the years. All the $F_{1}$ hybrids showed significant and positive SCH in $\mathrm{Y} 1, \mathrm{Y} 2$ and over the years. The outstanding hybrids over the standard check 'Indra' were MS-12 × PAU SM-31, MS-12 × PAU SM-9, MS-12 $\times$ PAU SM-3 in Y1, Y2 and across the two years. Total fruit yield plant ${ }^{-1}$ is one of the most important breeding objectives in any crop improvement program. In the current study, six, one and one hybrids showed significant positive $\mathrm{MPH}, \mathrm{BPH}$ and $\mathrm{SCH}$, respectively for total fruit yield plant ${ }^{-1}$ under $\mathrm{Y} 1$, whereas six and one hybrids expressed MPH and BPH under Y2, and six and one hybrids depicted MPH and BPH 
Table 3. Mean performance of parental lines over two years for horticultural traits in bell pepper

\begin{tabular}{|c|c|c|c|c|c|c|c|c|c|}
\hline \multirow{2}{*}{ Parents } & \multicolumn{3}{|c|}{ Plant height $(\mathrm{cm})^{\dagger}$} & \multicolumn{3}{|l|}{ Fruit weight $(\mathrm{g})^{\dagger}$} & \multicolumn{3}{|c|}{ Fruit length $(\mathrm{cm})^{\dagger}$} \\
\hline & Year 1 & Year 2 & Pooled & Year 1 & Year 2 & Pooled & Year 1 & Year 2 & Pooled \\
\hline MS-12 & $169.90 \pm 7.11 \mathrm{a}$ & $181.40 \pm 11.34 \mathrm{a}$ & 175.65 & $3.89 \pm 0.21 \mathrm{f}$ & $3.24 \pm 0.17 d$ & 3.57 & $4.69 \pm 0.25 c$ & $4.14 \pm 0.14 \mathrm{e}$ & 4.42 \\
\hline PAU SM-1 & $96.70 \pm 6.72 \mathrm{c}$ & $80.91 \pm 5.26 \mathrm{~cd}$ & 88.80 & $70.07 \pm 5.18 b$ & $81.22 \pm 3.68 \mathrm{a}$ & 75.65 & $6.16 \pm 0.27 b$ & $7.01 \pm 0.22 a b$ & 6.59 \\
\hline PAU SM-2 & $84.90 \pm 5.04 \mathrm{~cd}$ & $74.24 \pm 3.79 \mathrm{de}$ & 79.57 & $64.91 \pm 4.44 \mathrm{bc}$ & $76.58 \pm 4.54 \mathrm{a}$ & 70.75 & $6.98 \pm 0.24 a b$ & $6.37 \pm 0.25 \mathrm{bc}$ & 6.68 \\
\hline PAU SM-3 & $100.73 \pm 4.94 \mathrm{bc}$ & $83.03 \pm 4.42 \mathrm{~cd}$ & 91.88 & $89.40 \pm 4.83 \mathrm{a}$ & $78.22 \pm 4.98 \mathrm{a}$ & 83.81 & $6.77 \pm 0.32 \mathrm{~b}$ & $7.28 \pm 0.36 \mathrm{a}$ & 7.03 \\
\hline PAU SM-4 & $62.27 \pm 3.64$ ef & $78.24 \pm 4.74 \mathrm{~cd}$ & 70.25 & $74.36 \pm 4.15 b$ & $85.27 \pm 4.24 \mathrm{a}$ & 79.81 & $7.81 \pm 0.41 \mathrm{a}$ & $7.02 \pm 0.24 a b$ & 7.41 \\
\hline PAU SM-17 & $116.40 \pm 11.68 b$ & $132.19 \pm 6.90 \mathrm{~b}$ & 124.30 & $54.28 \pm 2.77 \mathrm{~cd}$ & $46.60 \pm 2.65 b$ & 50.44 & $4.90 \pm 0.15 c$ & $4.23 \pm 0.21 \mathrm{e}$ & 4.57 \\
\hline PAU SM-21 & $48.80 \pm 3.01 \mathrm{f}$ & $60.51 \pm 4.20 \mathrm{e}$ & 54.66 & $48.17 \pm 3.19 d$ & $40.15 \pm 1.85 b$ & 44.16 & $4.83 \pm 0.31 c$ & $5.51 \pm 0.27 \mathrm{~cd}$ & 5.17 \\
\hline PAU SM-31 & $76.03 \pm 6.93 \mathrm{de}$ & $94.20 \pm 4.76 \mathrm{c}$ & 85.12 & $17.68 \pm 1.04 \mathrm{e}$ & $15.14 \pm 1.06 \mathrm{c}$ & 16.41 & $6.94 \pm 0.38 a b$ & $7.76 \pm 0.43 a$ & 7.35 \\
\hline Grand mean & 91.05 & 96.26 & 93.66 & 51.95 & 52.95 & 52.45 & 6.03 & 6.01 & 6.02 \\
\hline CV (\%) & 10.39 & 11.09 & 13.12 & 12.32 & 10.96 & 14.06 & 9.04 & 8.32 & 10.12 \\
\hline LSD at $p=0.05$ & 16.38 & 18.47 & 14.34 & 11.08 & 10.05 & 8.61 & 0.94 & 0.87 & 0.71 \\
\hline \multirow{2}{*}{ Parents } & \multicolumn{3}{|l|}{ Fruit width $(\mathrm{cm})^{\dagger}$} & \multicolumn{3}{|c|}{ Pericarp thickness $(\mathrm{mm})^{\dagger}$} & \multicolumn{3}{|c|}{ Number of fruits plant ${ }^{-1 \dagger}$} \\
\hline & Year 1 & Year 2 & Pooled & Year 1 & Year 2 & Pooled & Year 1 & Year 2 & Pooled \\
\hline MS-12 & $1.30 \pm 0.07 f$ & $1.47 \pm 0.07 \mathrm{e}$ & 1.39 & $0.78 \pm 0.05 f$ & $0.90 \pm 0.06 \mathrm{~d}$ & 0.84 & $223.15 \pm 9.87 \mathrm{a}$ & $187.83 \pm 9.86 \mathrm{a}$ & 205.49 \\
\hline PAU SM-1 & $5.21 \pm 0.20 \mathrm{bc}$ & $6.18 \pm 0.23 b$ & 5.70 & $3.84 \pm 0.13 \mathrm{bcd}$ & $4.36 \pm 0.21 \mathrm{a}$ & 4.10 & $30.25 \pm 1.94 \mathrm{c}$ & $26.30 \pm 1.36 \mathrm{~cd}$ & 28.27 \\
\hline PAU SM-2 & $4.77 \pm 0.18 \mathrm{c}$ & $5.24 \pm 0.21 \mathrm{c}$ & 5.00 & $4.22 \pm 0.22 b$ & $3.70 \pm 0.21 \mathrm{~b}$ & 3.96 & $23.25 \pm 1.30 \mathrm{c}$ & $27.88 \pm 1.64 \mathrm{~cd}$ & 25.57 \\
\hline PAU SM-3 & $7.09 \pm 0.23 \mathrm{a}$ & $6.25 \pm 0.22 \mathrm{ab}$ & 6.67 & $4.90 \pm 0.22 \mathrm{a}$ & $4.30 \pm 0.23 a$ & 4.60 & $32.43 \pm 1.80 \mathrm{c}$ & $38.02 \pm 2.30 \mathrm{c}$ & 35.23 \\
\hline PAU SM-4 & $7.66 \pm 0.19 a$ & $6.96 \pm 0.39 a$ & 7.31 & $4.07 \pm 0.13 b c$ & $4.48 \pm 0.25 \mathrm{a}$ & 4.28 & $28.57 \pm 2.45 \mathrm{c}$ & $24.52 \pm 1.69 d$ & 26.55 \\
\hline PAU SM-9 & $5.40 \pm 0.16 b$ & $5.01 \pm 0.17 c$ & 5.21 & $3.60 \pm 0.10 \mathrm{~cd}$ & $3.26 \pm 0.15 b$ & 3.43 & $29.32 \pm 2.11 \mathrm{c}$ & $33.50 \pm 1.83 \mathrm{~cd}$ & 31.41 \\
\hline PAU SM-17 & $5.39 \pm 0.30 b$ & $4.81 \pm 0.28 \mathrm{c}$ & 5.10 & $3.43 \pm 0.14 \mathrm{~d}$ & $3.23 \pm 0.16 b$ & 3.33 & $34.46 \pm 2.79 \mathrm{c}$ & $30.84 \pm 1.84 \mathrm{~cd}$ & 32.65 \\
\hline PAU SM-21 & $4.12 \pm 0.15 d$ & $4.69 \pm 0.23 c$ & 4.41 & $4.14 \pm 0.26 b$ & $3.75 \pm 0.17 b$ & 3.94 & $30.50 \pm 2.11 \mathrm{c}$ & $26.93 \pm 1.51 \mathrm{~cd}$ & 28.71 \\
\hline PAU SM-31 & $2.56 \pm 0.11 \mathrm{e}$ & $2.98 \pm 0.12 d$ & 2.77 & $1.58 \pm 0.09 \mathrm{e}$ & $1.76 \pm 0.12 \mathrm{c}$ & 1.67 & $85.39 \pm 5.10 \mathrm{~b}$ & $71.30 \pm 3.96 \mathrm{~b}$ & 78.35 \\
\hline Grand mean & 4.83 & 4.84 & 4.84 & 3.40 & 3.31 & 3.35 & 57.48 & 51.90 & 54.69 \\
\hline CV (\%) & 6.88 & 8.69 & 10.16 & 8.79 & 9.24 & 10.47 & 12.70 & 13.43 & 17.28 \\
\hline LSD at $p=0.05$ & 0.58 & 0.73 & 0.57 & 0.52 & 0.53 & 0.41 & 12.63 & 12.06 & 11.02 \\
\hline
\end{tabular}

${ }^{\dagger}$ Mean \pm SEm; values followed by same letter are not significantly different by LSD at $p=0.05$ 
Table 3 (Cont.)

\begin{tabular}{|c|c|c|c|}
\hline \multirow{2}{*}{ Parents } & \multicolumn{3}{|c|}{ Total fruit yield plant $^{-1}(\mathrm{~g})^{\dagger}$} \\
\hline & Year 1 & Year 2 & Pooled \\
\hline MS-12 & $479.21 \pm 28.02 \mathrm{e}$ & $399.19 \pm 29.10 \mathrm{e}$ & 439.20 \\
\hline PAU SM-1 & $1793.40 \pm 83.62 \mathrm{~b}$ & $1987.10 \pm 86.50 a b$ & 1890.25 \\
\hline PAU SM-2 & $1560.44 \pm 49.62 \mathrm{c}$ & $1775.29 \pm 94.68 b$ & 1667.86 \\
\hline PAU SM-3 & $1846.78 \pm 137.89 a b$ & $2167.81 \pm 88.23 \mathrm{a}$ & 2007.29 \\
\hline PAU SM-4 & $2021.24 \pm 109.57$ a & $1846.18 \pm 84.67 b$ & 1933.71 \\
\hline PAU SM-9 & $1171.46 \pm 49.02 \mathrm{~d}$ & $1333.14 \pm 76.53 \mathrm{c}$ & 1252.30 \\
\hline PAU SM-17 & $1501.38 \pm 68.93 \mathrm{c}$ & $1396.82 \pm 83.64 \mathrm{c}$ & 1449.10 \\
\hline PAU SM-21 & $1164.98 \pm 58.37 \mathrm{~d}$ & $1002.64 \pm 71.04 \mathrm{~d}$ & 1083.81 \\
\hline PAU SM-31 & $1219.66 \pm 73.16 \mathrm{~d}$ & $1074.39 \pm 71.07 \mathrm{~d}$ & 1147.03 \\
\hline Grand mean & 1417.62 & 1442.50 & 1430.06 \\
\hline CV (\%) & 9.01 & 9.84 & 11.26 \\
\hline LSD at $p=0.05$ & 220.99 & 245.70 & 187.91 \\
\hline
\end{tabular}

† Mean \pm SEm; values followed by same letter are not significantly different by LSD at $p=0.05$ based on pooled mean.

based on pooled mean. The extent of MPH ranged from -23.93 to $100.46 \%$ in $\mathrm{Y} 1$, from -4.69 to $92.89 \%$ in $\mathrm{Y} 2$ and -14.31 to $96.68 \%$ pooled over the years. The $\mathrm{BPH}$ and $\mathrm{SCH}$ varied from -53.85 to $37.11 \%$ and -55.13 to $29.87 \%$ in $Y 1$, from -36.76 to $35.62 \%$ and -55.12 to $0.35 \%$ in $Y 2$, and -44.31 to $36.37 \%$ and -55.13 to $15.11 \%$ across the years, respectively. The MPH was high and positively significant for the hybrids MS $-12 \times$ PAU SM-31 followed by MS-12 $\times$ PAU SM-3, MS-12 $\times$ PAU SM-9 and MS-12 $\times$ PAU SM-21 under Y1, in the hybrids MS-12 $\times$ PAU SM-31 followed by MS-12 $\times$ PAU SM-21, MS-12 $\times$ PAU SM-3 and MS-12 $\times$ PAU SM2 under Y2, and in the hybrids MS-12 $\times$ PAU SM-31 followed by MS-12 $\times$ PAU SM-3, MS-12 $\times$ PAU SM-21 and MS-12 $\times$ PAU SM-2. Over the BP, the hybrid MS-12 $\times$ PAU SM-31 expressed the highest significant positive heterosis in Y1, Y2 and across the years. Earlier, Meena and coauthors [10] recorded extent of positive significant BPH for plant height from -14.37 to $36.67 \%$, for fruit weight from -58.90 to $34.16 \%$, for fruit length from -29.24 to $27.18 \%$, for fruit width from -27.27 to $15.36 \%$, for pericarp thickness from -43.53 to $28.87 \%$, for number of fruits plant ${ }^{-1}$ from -23.46 to $68.73 \%$, and for total fruit yield plant ${ }^{-1}$ from -34.96 to $108.72 \%$ over the environments in chilli pepper. Gözen and coauthors [41] mentioned up to $45.48 \%$ BPH for number of fruits plant ${ }^{-1}$ in bell pepper. The crosses namely Solan Bharpur $\times$ Yolo Wonder, Yolo Wonder $\times$ Nishath-1, California Wonder $\times$ UHFBP-3 California Wonder $\times$ Solan Bharpur and UHFBP-3 $\times$ KC-12 were identified as promising combinations [42]. Sharma and coauthors [43] reported that the $\mathrm{F}_{1}$ hybrids namely Rani Sel-1 × SSP, Rani Sel-1 $\times$ Sel-12-2-1, SSP $\times$ SP-316 and PRC-1 × California Wonder showed significant better parent and standard heterosis for marketable fruit yield plant ${ }^{-1}$ in bell pepper. Rao and coauthors [44] were found hybrid viz. Akra Mohini $\times$ IIHR-4107 exhibited the highest standard heterosis for fruit number (77.27\%). The $F_{1}$ hybrids of Arka Mohini $\times$ IIHR-4103, Arka Mohini $\times$ IIHR-4107, Arka Mohini $\times$ IIHR-3341 and Arka Basant $\times$ IIHR-4096 were identified as the best heterotic cross combinations.

Evaluation across the years is most important to identify stable $F_{1}$ hybrids in bell pepper. Pooled over the years, the hybrids namely MS-12 $\times$ PAU SM-21 had positive significant MPH for total fruit yield plant ${ }^{-1}$, number of fruits plant $^{-1}$, pericarp thickness, fruit length, and plant height. Apart from this cross-combination, the hybrids MS-12 $\times$ PAU SM-3 and MS-12 $\times$ PAU SM-9 also depicted MPH for total fruit yield plant ${ }^{-1}$, plant height, fruit length and number of fruits plant ${ }^{-1}$. Based on $\mathrm{BPH}$, the hybrid MS-12 $\times$ PAU SM-31 was found to be superior in respect of total fruit yield plant ${ }^{-1}$ and pericarp thickness. This hybrid is suitable for long distance transportation and export, and also suitable for processing pepper into hot paste.

\section{Correlation analysis of parental lines and heterotic hybrids}

Among the parents, a total thirteen correlations were observed to be significant (Figure 1). Total fruit yield plant ${ }^{-1}$ was absolutely associated with FWT, FL, FWT and PT, suggested that these traits are most important form selection view point to get high fruit yield in bell pepper. Instead of that, FWT was significantly and negatively associated with NFP. The results indicated that as the FWT increases NFP would be decreased. The negative association of FWT with NFP means that if there are more fruits on a plant, the bell pepper FWT will tend to be smaller as fruits will compete for space as well as for the nutrients. On the other 
Table 4. Mean performance of $F_{1}$ hybrids of bell pepper for horticultural traits (over the years)

\begin{tabular}{|c|c|c|c|c|c|c|}
\hline \multirow{2}{*}{$F_{1}$ hybrids } & \multicolumn{3}{|l|}{ Plant height $(\mathrm{cm})^{\dagger}$} & \multicolumn{3}{|l|}{ Fruit weight $(\mathrm{g})^{\dagger}$} \\
\hline & Year 1 & Year 2 & Pooled & Year 1 & Year 2 & Pooled \\
\hline MS-12 × PAU SM-1 & $193.23 \pm 10.33 \mathrm{ab}$ & $166.14 \pm 7.85 \mathrm{~cd}$ & 179.69 & $13.36 \pm 0.77 \mathrm{bc}$ & $15.84 \pm 0.90 \mathrm{a}$ & 14.60 \\
\hline MS-12 × PAU SM-2 & $212.23 \pm 10.77 \mathrm{ab}$ & $196.40 \pm 13.25 \mathrm{abc}$ & 204.32 & $12.89 \pm 0.49 \mathrm{bcd}$ & $14.27 \pm 0.63 a b$ & 13.58 \\
\hline MS-12 × PAU SM-3 & $200.52 \pm 10.08 \mathrm{ab}$ & $162.58 \pm 9.19 \mathrm{~d}$ & 181.55 & $16.46 \pm 1.15 \mathrm{a}$ & $14.25 \pm 0.76 \mathrm{abc}$ & 15.35 \\
\hline MS-12 × PAU SM-4 & $190.65 \pm 8.16 \mathrm{~b}$ & $173.62 \pm 11.54 \mathrm{bcd}$ & 182.14 & $14.29 \pm 0.56 \mathrm{~b}$ & $13.12 \pm 0.73 \mathrm{bc}$ & 13.71 \\
\hline MS-12 × PAU SM-9 & $137.33 \pm 10.21 \mathrm{c}$ & $115.43 \pm 6.60 \mathrm{e}$ & 126.38 & $9.17 \pm 0.52 f$ & $8.01 \pm 0.50 d$ & 8.59 \\
\hline MS-12 × PAU SM-21 & $113.44 \pm 7.84 \mathrm{c}$ & $98.13 \pm 5.86 \mathrm{e}$ & 105.79 & $11.34 \pm 0.47 \mathrm{cde}$ & $12.09 \pm 0.95 \mathrm{c}$ & 11.72 \\
\hline MS-12 × PAU SM-31 & $226.20 \pm 15.82 \mathrm{a}$ & $199.76 \pm 12.21 \mathrm{ab}$ & 212.98 & $10.62 \pm 0.57$ ef & $9.18 \pm 0.55 \mathrm{~d}$ & 9.90 \\
\hline Grand mean & 182.64 & 164.95 & 173.80 & 12.38 & 12.03 & 12.20 \\
\hline CV (\%) & 10.78 & 11.43 & 11.27 & 9.95 & 10.28 & 11.71 \\
\hline LSD at $p=0.05$ & 34.49 & 33.03 & 22.98 & 2.16 & 2.16 & 1.68 \\
\hline$F_{1}$ hybrids & Year 1 & Year 2 & Pooled & Year 1 & Year 2 & Pooled \\
\hline MS-12 × PAU SM-1 & $10.52 \pm 0.46 \mathrm{a}$ & $9.15 \pm 0.50 \mathrm{a}$ & 9.84 & $2.41 \pm 0.14 a b$ & $2.05 \pm 0.12 b c$ & 2.23 \\
\hline MS-12 × PAU SM-2 & $7.43 \pm 0.37 \mathrm{bcd}$ & $8.02 \pm 0.46 \mathrm{abc}$ & 7.73 & $2.39 \pm 0.16 a b$ & $2.93 \pm 0.16 \mathrm{a}$ & 2.66 \\
\hline MS-12 × PAU SM-3 & $7.76 \pm 0.35 \mathrm{bc}$ & $8.49 \pm 0.49 a b$ & 8.12 & $2.70 \pm 0.16 \mathrm{a}$ & $2.36 \pm 0.17 \mathrm{~b}$ & 2.53 \\
\hline MS-12 × PAU SM-4 & $6.02 \pm 0.21 \mathrm{e}$ & $5.28 \pm 0.29 d$ & 5.65 & $2.25 \pm 0.14 \mathrm{bc}$ & $2.01 \pm 0.11 \mathrm{bc}$ & 2.13 \\
\hline MS-12 × PAU SM-9 & $8.39 \pm 0.46 b$ & $7.41 \pm 0.38 \mathrm{bc}$ & 7.90 & $1.88 \pm 0.12 \mathrm{~cd}$ & $2.20 \pm 0.14 \mathrm{bc}$ & 2.04 \\
\hline MS-12 × PAU SM-17 & $6.45 \pm 0.35 \mathrm{de}$ & $7.20 \pm 0.36 \mathrm{c}$ & 6.83 & $1.80 \pm 0.12 \mathrm{~d}$ & $1.52 \pm 0.08 d$ & 1.66 \\
\hline MS-12 × PAU SM-21 & $6.82 \pm 0.26 \mathrm{cde}$ & $7.55 \pm 0.28 \mathrm{bc}$ & 7.18 & $2.49 \pm 0.14 a b$ & $2.96 \pm 0.11 \mathrm{a}$ & 2.73 \\
\hline MS-12 × PAU SM-31 & $7.69 \pm 0.27 \mathrm{bc}$ & $7.11 \pm 0.28 \mathrm{c}$ & 7.40 & $1.62 \pm 0.11 \mathrm{~d}$ & $1.95 \pm 0.09 c$ & 1.79 \\
\hline Grand mean & 7.64 & 7.53 & 7.58 & 2.19 & 2.25 & 2.22 \\
\hline CV (\%) & 8.08 & 9.08 & 10.05 & 11.48 & 10.32 & 13.72 \\
\hline LSD at $p=0.05$ & 1.08 & 1.20 & 0.89 & 0.44 & 0.41 & 0.36 \\
\hline
\end{tabular}

${ }^{\dagger}$ Mean \pm SEm; values followed by same letter are not significantly different by LSD at $p=0.05$ 
Table 4 (Cont.)

\begin{tabular}{|c|c|c|c|c|c|c|c|c|c|}
\hline \multirow{2}{*}{$\mathrm{F}_{1}$ hybrids } & \multicolumn{3}{|c|}{ Pericarp thickness $(\mathrm{mm})^{\dagger}$} & \multicolumn{3}{|c|}{ Number of fruits plant ${ }^{-1 \dagger}$} & \multicolumn{3}{|c|}{ Total fruit yield plant $^{-1}(\mathrm{~g})^{\dagger}$} \\
\hline & Year 1 & Year 2 & Pooled & Year 1 & Year 2 & Pooled & Year 1 & Year 2 & Pooled \\
\hline MS-12 × PAU SM-1 & $2.05 \pm 0.11 \mathrm{bc}$ & $1.90 \pm 0.08$ & 1.98 & $130.84 \pm 7.59 \mathrm{c}$ & $116.39 \pm 5.97 \mathrm{cde}$ & 123.62 & $1505.98 \pm 76.76 \mathrm{bc}$ & $1711.89 \pm 79.59 \mathrm{a}$ & 1608.93 \\
\hline MS-12 × PAU SM-2 & $1.88 \pm 0.11 \mathrm{c}$ & $2.21 \pm 0.13$ & 2.05 & $119.74 \pm 5.18 \mathrm{c}$ & $132.29 \pm 7.74 \mathrm{~cd}$ & 126.01 & $1449.42 \pm 95.68 \mathrm{c}$ & $1698.23 \pm 76.43 a b$ & 1573.82 \\
\hline MS-12 × PAU SM-3 & $2.27 \pm 0.16 a b$ & $2.01 \pm 0.07$ & 2.14 & $164.23 \pm 9.89 \mathrm{~b}$ & $142.92 \pm 11.74 \mathrm{bc}$ & 153.57 & $2270.63 \pm 97.81 \mathrm{a}$ & $1921.19 \pm 126.11 \mathrm{a}$ & 2095.91 \\
\hline MS-12 × PAU SM-4 & $1.85 \pm 0.11 \mathrm{c}$ & $2.09 \pm 0.14$ & 1.97 & $92.27 \pm 5.01 \mathrm{de}$ & $105.49 \pm 6.05 \mathrm{e}$ & 98.88 & $1049.71 \pm 57.60 \mathrm{~d}$ & $1226.11 \pm 57.37 \mathrm{c}$ & 1137.91 \\
\hline MS-12 × PAU SM-9 & $2.36 \pm 0.14 a b$ & $2.10 \pm 0.10$ & 2.23 & $178.16 \pm 9.83 b$ & $164.72 \pm 8.72 b$ & 171.44 & $1411.78 \pm 74.76 \mathrm{c}$ & $1247.68 \pm 62.05 \mathrm{c}$ & 1329.73 \\
\hline MS-12 $\times$ PAU SM-17 & $1.45 \pm 0.08 d$ & $1.69 \pm 0.11$ & 1.57 & $90.68 \pm 5.70 \mathrm{e}$ & $107.38 \pm 6.08 \mathrm{de}$ & 99.03 & $704.06 \pm 49.68 \mathrm{e}$ & $855.62 \pm 49.29 \mathrm{~d}$ & 779.84 \\
\hline MS-12 × PAU SM-21 & $2.50 \pm 0.15 a$ & $2.20 \pm 0.12$ & 2.35 & $118.10 \pm 4.18 \mathrm{~cd}$ & $106.38 \pm 7.32 \mathrm{de}$ & 112.24 & $1284.03 \pm 66.15 \mathrm{c}$ & $1123.10 \pm 82.73 \mathrm{c}$ & 1203.56 \\
\hline MS-12 $\times$ PAU SM-31 & $1.70 \pm 0.11 \mathrm{~cd}$ & $2.02 \pm 0.11$ & 1.86 & $232.03 \pm 16.35 \mathrm{a}$ & $199.35 \pm 12.84 \mathrm{a}$ & 215.69 & $1706.22 \pm 95.51 b$ & $1478.68 \pm 55.76 \mathrm{~b}$ & 1592.45 \\
\hline Grand mean & 2.01 & 2.03 & 2.02 & 140.75 & 134.36 & 137.56 & 1422.73 & 1407.81 & 1415.27 \\
\hline CV (\%) & 10.56 & 9.63 & 11.90 & 10.67 & 11.31 & 12.22 & 9.31 & 9.17 & 12.26 \\
\hline LSD at $p=0.05$ & 0.37 & - & 0.28 & 26.30 & 26.62 & 19.71 & 232.07 & 226.16 & 203.43 \\
\hline
\end{tabular}

${ }^{\dagger}$ Mean \pm SEm; values followed by same letter are not significantly different by LSD at $p=0.05$

Table 5. Estimates of heterosis (\%) over better parent (BPH) and standard check (SCH) exhibited by eight hybrids for plant growth and yield traits evaluated over two years

\begin{tabular}{|c|c|c|c|c|c|c|c|c|c|}
\hline \multirow{3}{*}{$\mathrm{F}_{1}$ hybrids } & \multicolumn{9}{|c|}{ Plant height $(\mathrm{cm})$} \\
\hline & \multicolumn{3}{|c|}{ Year 1} & \multicolumn{3}{|l|}{ Year 2} & \multicolumn{3}{|l|}{ Pooled } \\
\hline & $\mathrm{MPH}$ & $\mathrm{BPH}$ & $\mathrm{SCH}$ & $\mathrm{MPH}$ & $\mathrm{BPH}$ & $\mathrm{SCH}$ & $\mathrm{MPH}$ & $\mathrm{BPH}$ & $\mathrm{SCH}$ \\
\hline MS-12 × PAU SM-1 & $44.96^{\star \star}$ & 13.73 & $68.66^{\star *}$ & 26.68 & -8.41 & $68.77^{\star *}$ & $35.89^{\star *}$ & 2.30 & $68.71^{* *}$ \\
\hline MS $-12 \times$ PAU SM- 2 & $66.59^{* *}$ & $24.91^{*}$ & $85.25^{\star *}$ & $53.66^{* *}$ & 8.27 & $99.51^{* *}$ & $60.11^{* *}$ & 16.32 & $91.84^{\star *}$ \\
\hline MS-12 × PAU SM-3 & $48.18^{\star *}$ & 18.02 & $75.02^{\star *}$ & 22.97 & -10.38 & $65.15^{\star *}$ & $35.72^{\star \star}$ & 3.36 & $70.46^{\star *}$ \\
\hline MS-12 × PAU SM-4 & $64.24^{\star \star}$ & 12.22 & $66.41^{\star \star}$ & $33.74 *$ & -4.29 & $76.36^{\star \star}$ & $48.14^{\star \star}$ & 3.69 & $71.01^{\star \star}$ \\
\hline MS-12 × PAU SM-9 & 17.56 & -19.17 & 19.87 & -12.22 & $-36.37^{* *}$ & 17.26 & 1.79 & $-28.05^{*}$ & 18.66 \\
\hline MS-12 × PAU SM-17 & $31.00^{* *}$ & 10.37 & $63.68^{\star *}$ & $32.39^{\star *}$ & 14.43 & $110.86^{* *}$ & $31.72^{*}$ & 12.47 & $85.48^{\star *}$ \\
\hline MS-12 × PAU SM-21 & 3.74 & $-33.23^{* *}$ & -0.99 & -18.87 & $-45.90^{\star *}$ & -0.31 & -8.14 & $-39.77^{\star *}$ & -0.68 \\
\hline MS-12 × PAU SM-31 & $83.95^{\star *}$ & $33.14^{*}$ & $97.44^{\star *}$ & $44.96^{* *}$ & 10.12 & $102.92^{\star *}$ & $63.35^{\star *}$ & 21.25 & $99.97^{* *}$ \\
\hline Mean heterosis (\%) & 45.03 & 7.50 & 59.42 & 22.91 & -9.07 & 67.57 & 33.57 & -1.05 & 63.18 \\
\hline LSD at $p=0.05$ & 29.67 & 24.23 & 24.23 & 29.42 & 24.02 & 24.02 & 23.99 & 27.70 & 27.70 \\
\hline LSD at $p=0.01$ & 39.84 & 32.53 & 32.53 & 39.50 & 32.25 & 32.25 & 32.20 & 37.19 & 37.19 \\
\hline \multirow{3}{*}{$F_{1}$ hybrids } & \multicolumn{9}{|c|}{ Fruit weight $(\mathrm{g})$} \\
\hline & \multicolumn{3}{|c|}{ Year 1} & \multicolumn{3}{|l|}{ Year 2} & \multicolumn{3}{|l|}{ Pooled } \\
\hline & MPH & $\mathrm{BPH}$ & $\mathrm{SCH}$ & MPH & $\mathrm{BPH}$ & $\mathrm{SCH}$ & $\mathrm{MPH}$ & $\mathrm{BPH}$ & $\mathrm{SCH}$ \\
\hline MS-12 × PAU SM-1 & $-63.86^{\star *}$ & $-80.93^{* *}$ & $-86.13^{* *}$ & $-62.50^{* *}$ & $-80.50^{\star *}$ & $-85.37^{* *}$ & $-63.14^{* *}$ & $-80.70^{* *}$ & $-85.73^{\star *}$ \\
\hline MS-12 $\times$ PAU SM-2 & $-62.54^{* *}$ & $-80.15^{\star \star}$ & $-86.62^{\star *}$ & $-64.24^{\star *}$ & $-81.36^{\star *}$ & $-86.82^{\star *}$ & $-63.45^{\star *}$ & $-80.81^{\star *}$ & $-86.72^{\star \star}$ \\
\hline MS-12 × PAU SM-3 & $-64.72^{\star *}$ & $-81.59^{\star *}$ & $-82.91^{\star *}$ & $-65.01^{* *}$ & $-81.78^{\star *}$ & $-86.84^{\star *}$ & $-64.86^{\star *}$ & $-81.68^{\star *}$ & $-84.99^{* *}$ \\
\hline MS-12 × PAU SM-4 & $-63.47^{\star *}$ & $-80.78^{\star *}$ & $-85.16^{\star *}$ & $-70.35^{\star *}$ & $-84.61^{* *}$ & $-87.88^{\star *}$ & $-67.12^{\star \star}$ & $-82.83^{\star *}$ & $-86.60^{\star *}$ \\
\hline MS-12 × PAU SM-17 & $-62.59^{\star *}$ & $-79.96^{\star *}$ & $-88.70^{\star *}$ & $-62.00^{\star *}$ & $-79.68^{* *}$ & $-91.25^{\star *}$ & $-62.32^{\star *}$ & $-79.83^{\star *}$ & $-90.05^{\star *}$ \\
\hline
\end{tabular}




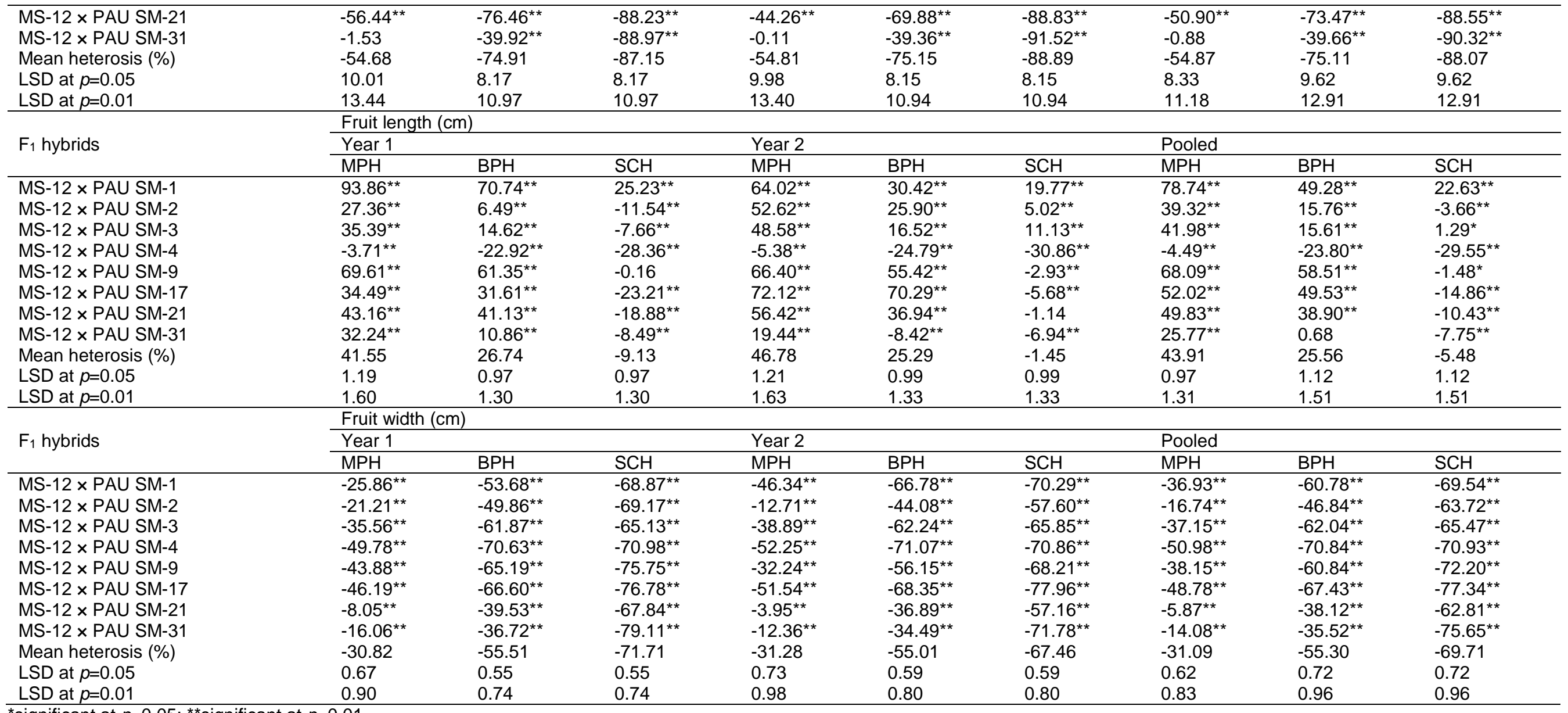

*significant at $p=0.05 ;{ }^{* *}$ significant at $p=0.01$ 
Table 5 (Cont.)

\begin{tabular}{|c|c|c|c|c|c|c|c|c|c|}
\hline \multirow{3}{*}{$F_{1}$ hybrids } & \multicolumn{9}{|c|}{ Pericarp thickness (mm) } \\
\hline & \multicolumn{3}{|c|}{ Year 1} & \multicolumn{3}{|l|}{ Year 2} & \multicolumn{3}{|l|}{ Pooled } \\
\hline & $\mathrm{MPH}$ & $\mathrm{BPH}$ & $\mathrm{SCH}$ & $\mathrm{MPH}$ & $\mathrm{BPH}$ & $\mathrm{SCH}$ & $\mathrm{MPH}$ & $\mathrm{BPH}$ & $\mathrm{SCH}$ \\
\hline MS-12 × PAU SM-1 & $-11.11^{\star \star}$ & $-46.48^{\star \star}$ & $-59.02^{\star \star}$ & $-27.80^{\star *}$ & $-56.42^{\star *}$ & $-56.46^{\star *}$ & $-20.00^{\star *}$ & $-51.77^{\star \star}$ & $-57.82^{\star \star}$ \\
\hline MS-12 × PAU SM-2 & $-24.85^{\star \star}$ & $-55.45^{\star \star}$ & $-62.48^{\star \star}$ & $-4.05^{\star \star}$ & $-40.32^{\star \star}$ & $-49.35^{\star \star}$ & $-14.88^{* *}$ & $-48.38^{\star \star}$ & $-56.37^{\star \star}$ \\
\hline MS-12 x PAU SM-4 & $-23.68^{\star \star}$ & $-54.50^{\star *}$ & $-63.01^{* *}$ & $-22.35^{\star *}$ & $-53.35^{\star \star}$ & $-52.10^{\star *}$ & $-22.98^{* *}$ & $-53.90^{\star *}$ & $-57.93^{\star \star}$ \\
\hline MS- 12 × PAU SM-9 & $7.83^{\star *}$ & $-34.35^{\star \star}$ & $-52.83^{\star *}$ & $0.88^{\star *}$ & $-35.58^{\star *}$ & $-51.87^{\star *}$ & $4.45^{\star *}$ & $-34.94^{\star *}$ & $-52.38^{\star *}$ \\
\hline MS- $12 \times$ PAU SM- 17 & $-31.01^{* *}$ & $-57.63^{\star *}$ & $-70.99^{\star *}$ & $-18.13^{\star *}$ & $-47.63^{\star *}$ & $-61.19^{\star *}$ & $-24.63^{* *}$ & $-52.78^{\star \star}$ & $-66.43^{\star *}$ \\
\hline MS-12 x PAU SM-21 & $1.63^{\star *}$ & $-39.57^{* *}$ & $-50.10^{\star *}$ & $-5.30^{\star *}$ & $-41.25^{\star \star}$ & $-49.50^{\star *}$ & $-1.74^{\star *}$ & $-40.36^{\star \star}$ & $-49.82^{\star \star}$ \\
\hline MS-12 x PAU SM-31 & $43.66^{\star \star}$ & $7.37^{\star *}$ & $-66.07^{\star *}$ & $51.69^{\star \star}$ & $14.77^{\star \star}$ & $-53.71^{* *}$ & $47.91^{\star *}$ & $11.27^{\star \star}$ & $-60.31^{\star *}$ \\
\hline Mean heterosis (\%) & -7.2 & -41.78 & -59.90 & -5.98 & -39.13 & -53.51 & -6.65 & -40.54 & -56.93 \\
\hline LSD at $p=0.05$ & 0.57 & 0.47 & 0.47 & 0.53 & 0.43 & 0.43 & 0.45 & 0.52 & 0.52 \\
\hline \multirow[t]{2}{*}{ LSD at $p=0.01$} & 0.77 & 0.63 & 0.63 & 0.71 & 0.58 & 0.58 & 0.61 & 0.70 & 0.70 \\
\hline & \multicolumn{9}{|c|}{ Number of fruits plant ${ }^{-1}$} \\
\hline \multirow[t]{2}{*}{$F_{1}$ hybrids } & \multicolumn{3}{|c|}{ Year 1} & \multicolumn{3}{|l|}{ Year 2} & \multicolumn{3}{|l|}{ Pooled } \\
\hline & $\mathrm{MPH}$ & $\mathrm{BPH}$ & $\mathrm{SCH}$ & $\mathrm{MPH}$ & $\mathrm{BPH}$ & $\mathrm{SCH}$ & $\mathrm{MPH}$ & $\mathrm{BPH}$ & $\mathrm{SCH}$ \\
\hline MS-12 × PAU SM-1 & 3.27 & $-41.37^{\star *}$ & $321.07^{* *}$ & 8.71 & $-38.03^{\star *}$ & $381.75^{\star *}$ & 5.76 & $-39.84^{\star *}$ & $347.61^{\star *}$ \\
\hline MS-12 × PAU SM-2 & -2.81 & $-46.34^{\star \star}$ & $285.34^{* *}$ & $22.66^{*}$ & $-29.57^{* *}$ & $447.56^{\star *}$ & 9.08 & $-38.68^{\star \star}$ & $356.29^{* *}$ \\
\hline MS-12 $\times$ PAU SM-3 & $28.51^{*}$ & $-26.41^{\star *}$ & $428.51^{* *}$ & $26.56^{*}$ & $-23.91^{* *}$ & $491.54^{* *}$ & $27.60^{\star *}$ & $-25.27^{\star}$ & $456.08^{* *}$ \\
\hline MS-12 × PAU SM-4 & $-26.69^{\star}$ & $-58.65^{\star \star}$ & $196.93^{\star *}$ & -0.64 & $-43.83^{\star \star}$ & $336.64^{\star \star}$ & -14.77 & $-51.88^{\star \star}$ & $258.04^{\star \star}$ \\
\hline MS $-12 \times$ PAU SM -17 & $-29.60^{* *}$ & $-59.36^{* *}$ & $191.84^{* *}$ & -1.79 & $-42.83^{\star *}$ & $344.45^{\star *}$ & -16.83 & $-51.81^{* *}$ & 258.59 ** \\
\hline MS-12 x PAU SM-21 & -6.88 & $-47.08^{\star *}$ & $280.07^{* *}$ & -0.93 & $-43.36^{\star *}$ & $340.33^{* *}$ & -4.15 & $-45.38^{\star \star}$ & $306.43^{* *}$ \\
\hline MS-12 x PAU SM-31 & $50.40^{* *}$ & 3.98 & $646.71^{* *}$ & $53.86^{\star *}$ & 6.13 & $725.11^{* *}$ & $51.98^{\star \star}$ & 4.96 & $681.00^{* *}$ \\
\hline Mean heterosis (\%) & 12.75 & -42.33 & 369.57 & 43.09 & -38.48 & 469.97 & 41.44 & -43.59 & 413.49 \\
\hline LSD at $p=0.05$ & 23.20 & 18.94 & 18.94 & 22.65 & 18.50 & 18.50 & 18.51 & 21.37 & 21.37 \\
\hline LSD at $p=0.01$ & 31.15 & 25.43 & 25.43 & 30.41 & 24.83 & 24.83 & 24.85 & 28.69 & 28.69 \\
\hline
\end{tabular}

*significant at $p=0.05 ;{ }^{* *}$ significant at $p=0.01$ 
Table 5 (Cont.)

\begin{tabular}{|c|c|c|c|c|c|c|c|c|c|}
\hline \multirow{3}{*}{$\mathrm{F}_{1}$ hybrids } & \multicolumn{9}{|c|}{ Total fruit yield plant ${ }^{-1}(\mathrm{~g})$} \\
\hline & \multicolumn{3}{|c|}{ Year 1} & \multicolumn{3}{|l|}{ Year 2} & \multicolumn{3}{|l|}{ Pooled } \\
\hline & $\mathrm{MPH}$ & $\mathrm{BPH}$ & $\mathrm{SCH}$ & $\mathrm{MPH}$ & $\mathrm{BPH}$ & $\mathrm{SCH}$ & MPH & $\mathrm{BPH}$ & $\mathrm{SCH}$ \\
\hline MS-12 x PAU SM-1 & $42.50^{*}$ & -9.64 & -9.42 & $41.14^{* *}$ & -13.91 & -9.16 & $41.82^{*}$ & -11.78 & -9.29 \\
\hline MS-12 × PAU SM-2 & $52.14^{\star *}$ & -1.60 & -9.85 & $49.47^{* *}$ & -6.84 & -12.3 & $50.81^{* *}$ & -4.22 & -11.08 \\
\hline MS-12 × PAU SM-4 & -23.34 & $-53.85^{\star *}$ & $-39.22^{* *}$ & 5.46 & $-34.76^{* *}$ & $-36.18^{* *}$ & -8.94 & $-44.31^{* *}$ & $-37.70^{\star *}$ \\
\hline MS-12 × PAU SM-9 & $65.93^{* *}$ & 15.96 & -21.59 & $35.34^{*}$ & -10.52 & $-35.57^{\star *}$ & $50.64^{* *}$ & 2.72 & $-28.58^{*}$ \\
\hline MS-12 × PAU SM-17 & -23.93 & $-50.74^{\star *}$ & $-55.13^{* *}$ & -4.69 & $-36.76^{\star *}$ & $-55.12^{* *}$ & -14.31 & $-43.75^{\star *}$ & $-55.13^{\star \star}$ \\
\hline MS-12 × PAU SM-21 & $55.42^{\star *}$ & 8.79 & -26.85 & $51.95^{\star *}$ & 6.69 & $-38.76^{\star *}$ & $53.69^{* *}$ & 7.74 & $-32.81^{*}$ \\
\hline Mean heterosis (\%) & 45.23 & -4.21 & -16.50 & 40.17 & -8.74 & -26.16 & 42.7 & -6.48 & -21.33 \\
\hline LSD at $p=0.05$ & 34.12 & 27.86 & 27.86 & 30.37 & 24.79 & 24.79 & 32.25 & 26.33 & 26.33 \\
\hline LSD at $p=0.01$ & 45.80 & 37.40 & 37.40 & 40.77 & 33.29 & 33.29 & 43.29 & 35.35 & 35.35 \\
\hline
\end{tabular}

*significant at $p=0.05 ;$ ** significant at $p=0.01$ 


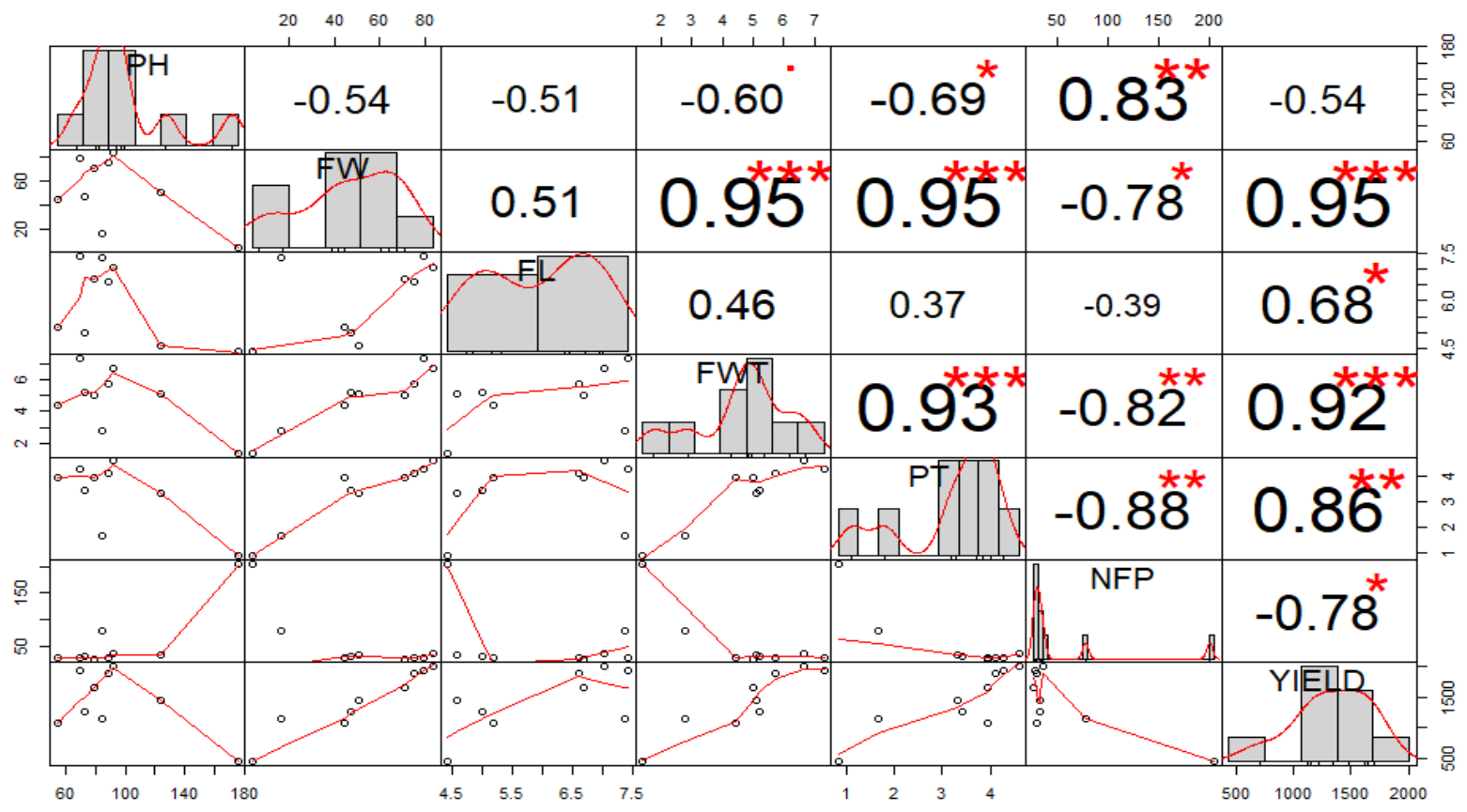

Figure 1. Pearson's correlation coefficients of parental lines of peppers with significant values at $p<0.001\left(^{* \star *}\right), p<$ $0.01\left(^{* *}\right)$, or $p<0.05\left(^{*}\right)$

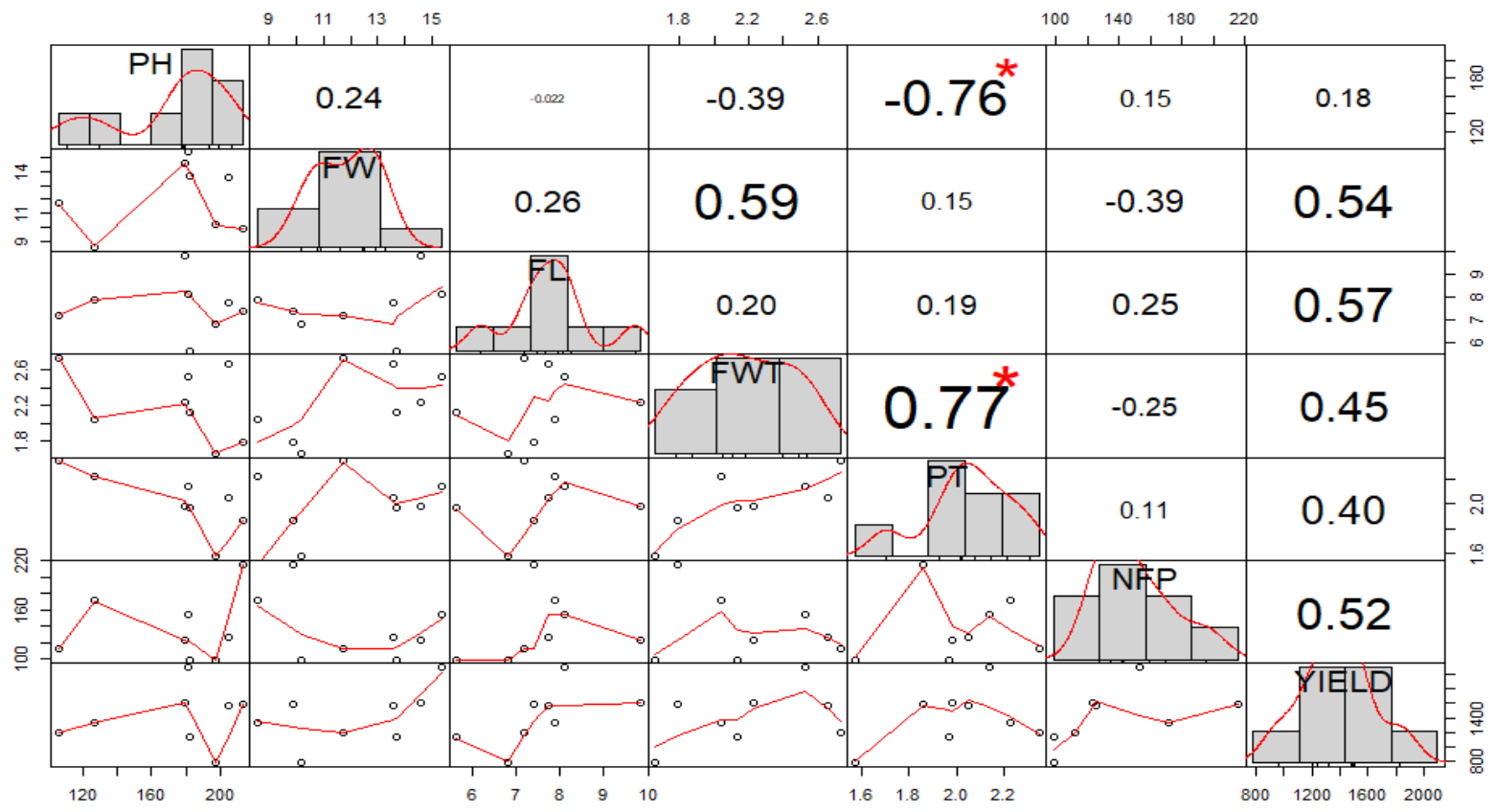

Figure 2. Pearson's correlation coefficients of hybrids of peppers with significant values at $p<0.05$.

hand, FW positive correlation with FWT, PT and YP, which indicated that as the FW increases all the above mentioned traits would also be increased. In the case of $F_{1}$ 's, two correlations were determined to be significant ( $p=0.05$ ) (Figure 2). FW, FL, FWT, PT and NFP were positively correlated with total fruit yield plant 1 . This association revealed that the selection for higher fruit yield plant ${ }^{-1}$ will be effective for isolating plants with higher FW followed by FL, FWT, PT and NFP from the genotypes studied. Previous research work conducted on chilli pepper by Aiswarya and coauthors [45] showed similar results. One of the associations was absolute (0.77), that between the FWT and PT. In Capsicum, fruit that express larger width will more likely have more potential to produce fruit with higher weight and thicker pericarp [10]. Ben-Chaim and Paran [46] also reported highly positive genetic association of FWT and PT. 


\section{CONCLUSION}

The major goals of the present article were to assess the effect of genetic distance between parents on fruit yield of chilli pepper $\times$ bell pepper hybrids, and to detect association between studied traits. On the basis of heterotic performance, the hybrids namely MS-12 × PAU SM-21 had positive significant MPH for YP, NFP, PT, FL, and PH. The hybrids MS-12 × PAU SM-3 and MS-12 $\times$ PAU SM-9 also depicted MPH for YP, PH, FL and NFP. Based on BPH, the hybrid MS-12 $\times$ PAU SM-31 was found to be superior in respect of YP and PT, therefore this hybrid is suitable for long distance transportation and export, and also suitable for processing pepper into hot paste. The material developed from this research helps to extent genetic variability already existing in Capsicum. Apart from this, all the hybrids were used to developed segregating and backcross populations for screening and successful introgression of $\mathrm{ms} 10$ gene from hot pepper to bell pepper. The newly established non-pungent bell pepper NMS lines from this proposed research would reinforce the bell pepper heterosis breeding system, and these developed NMS lines is expected to be used as a seed parent for $F_{1}$ hybrids of bell pepper.

Funding: Financial support provided by Department of Biotechnology (DBT), Government of India, New Delhi, India (Grant number: BT/PR21462/ BPA/118/220/2016), is gratefully acknowledged.

Conflicts of Interest: We have no conflicts of interest to disclose.

\section{REFERENCES}

1. Pickersgill B. Cytogenetics and evolution of Capsicum L. In: Tsuchiya T, Gupta PK, editors. Chromosome engineering in plants: Genetics, breeding, evolution, Part B. Amsterdam: Elsevier; 1991. p. 139-60.

2. Barboza GE, Carrizo Garcia C, Leiva Gonzalez S, Scaldaferro M, Reyes X. Four new species of Capsicum (Solanaceae) from the tropical Andes and an update on the phylogeny of the genus. PLoS ONE. 2019;14(1):e0209792.

3. Bianchi PA, da Silva LRA, Alencar AAS, Santos PHAD, Pimenta S, Sudré CP, et al. Biomorphological characterization of Brazilian Capsicum chinense Jacq. germplasm. Agron. 2020;10: 447.

4. Bosland PW. Chiles: a diverse crop. HortTechnol. 1992;2:6-10.

5. $\quad$ Pickersgill B. Genetic resources and breeding of Capsicum spp. Euphytica. 1997;96:129-33.

6. $\quad$ Wang D, Bosland PW. The genes of Capsicum. HortSci. 2006;41:1169-87.

7. Tanksley SD. High rates of cross-pollination in chile pepper. HortSci. 1984;19:580-82.

8. Meena OP, Dhaliwal MS, Jindal SK. Development of cytoplasmic male sterile lines in chilli (Capsicum annuum L.) and their evaluation across multiple environments. Breed Sci. 2018;68:404-12.

9. Anonymous. Area of bell pepper (ha) and production quantity (tonnes) in 2018-19. In: Third Advance Estimate of Area and Production of Horticulture Crops. 2019; www.nhb.gov.in.

10. Meena OP, Dhaliwal MS, Jindal SK. Heterosis breeding in chilli pepper by using cytoplasmic male sterile lines for high-yield production with special reference to seed and bioactive compound content under temperature stress regimes. Sci Hortic. 2020a;262:109036.

11. Yang CJ, Chen BJ, Liu JG, Li S. Study on the superiority of hybrid breeding by male sterility in hot pepper. J China Capsicum. 2008;1:36-38.

12. Meena OP, Dhaliwal MS, Jindal SK, Rani M. Cytoplasmic male sterile lines with desirable combining ability enhance the concentration of biochemical attributes and total yield in Capsicum annuum under temperature stress conditions. Ind Crops Prod. 2020b;145:112107.

13. Dhaliwal MS, Jindal SK. Induction and exploitation of nuclear and cytoplasmic male sterility in pepper (Capsicum spp.): a review. J Hort Sci Biotechnol. 2014;89:471-79.

14. Jindal SK, Dhaliwal MS, Meena OP. Molecular advancements in male sterility systems of Capsicum: a review. Plant Breed. 2020;139:42-64.

15. Martin JA, Crawford JH. Several types of sterility in Capsicum frutescens. Proc Am Soc Hort Sci. 1951;57:33538.

16. Pochard E. Induction of three new male-sterility mutants in pepper (Capsicum annuum L.) by mutagenic treatment of monoploid material. In: Male sterility in plants (Horticulture), Proc of the Eucarpia Meeting (B Schweisguth), (Versailles), 1970;93-5.

17. Singh J, Kaur S. Present status of hot pepper breeding for multiple disease resistance in Punjab. In: Genetics and Breeding of Capsicum and Eggplant, Proc VIth EUCARPIA meeting; Zaragoza, Spain. 1986. p. 111-14.

18. Rani M. Marker assisted breeding for introgression of genetic male sterile ms10 gene from hot pepper to heat tolerant bell pepper [dissertation]. Ludhiana, India: Punjab Agricultural University; 2020.

19. Hundal JS, Khurana DS. CH-1- a new hybrid of chilli. Prog Fmg. 1993;29:11-13.

20. Hundal JS, Khurana DS. A new hybrid of chilli ' $\mathrm{CH}-3$ '- suitable for processing. J Res Punjab agric Univ. 2002;39:326.

21. Dhaliwal MS, Jindal SK, Cheema DS. CH-27, a multiple disease resistant chilli hybrid. Agric Res J. 2015;52:12729. 
22. Ben-Chaim A, Paran I, Grube RC, Jahn M, van Wijk R, Peleman J. QTL mapping of fruit-related traits in pepper (Capsicum annuum). Theor Appl Genet. 2001;102:1016-28.

23. Barchi L, Bonnet J, Boudet C, Signoret P, Nagy I, Lanteri S, et al. A high-resolution, intraspecific linkage map of pepper (Capsicum annuum L.) and selection of reduced recombinant inbred line subsets for fast mapping. Genome. 2007;50:51-60.

24. Mimura Y, Inoue T, Minamiyama Y, Kubo N. An SSR-based genetic map of pepper (Capsicum annuum L.) serves as an anchor for the alignment of major pepper maps. Breed Sci. 2012;62:93-8.

25. Zhang XF, Wang GY, Dong TT, Chen B, Du HS, Li CB, et al. High-density genetic map construction and QTL mapping of first flower node in pepper (Capsicum annuum L.). BMC Plant Biol. 2019;19:167.

26. Olszewska D, Jędrzejczyk I, Nowaczyk P. Biometrical assessment of interspecific hybrids of Capsicum genus. Veg Crop Res Bull. 2011;75:21-30.

27. Anonymous. Sweet Pepper. In: Package of practices for cultivation of vegetables. Ludhiana, India: Punjab Agricultural University; 2015. p. 53-55.

28. RStudio Team. RStudio: Integrated Development for R. RStudio, Inc., Boston, MA, 2015, http://www.rstudio.com/

29. Falconer DS, Mackay TFC. Introduction to Quantitative Genetics, 4th ed. Longman Group Limited, U.K., 1996.

30. Singh P, Cheema DS, Dhaliwal MS, Garg N. Heterosis and combining ability for earliness, plant growth, yield and fruit attributes in hot pepper (Capsicum annuum L.) involving genetic and cytoplasmic-genetic male sterile lines. Sci Hortic. 2014;168:175-88.

31. Sreenivas M, Bhattacharjee T, Sharangi AB, Maurya PK, Banerjee S, Chatterjee S, et al. Breeding chili pepper for simultaneous improvement in dry fruit yield, fruit quality and leaf curl virus disease tolerance. Int J Veg Sci. 2019;25:1-30.

32. Devi MB, Pathania NK. Heterosis studies in bell pepper (Capsicum annuum L. var. grossum Sendt) under modified naturally ventilated polyhouse in mid hills of Himalayas. Veg Sci. 2018;45:31-37.

33. Meena OP. Evaluation of cytoplasmic male sterile lines of chilli pepper (Capsicum annuum L.) and their utilization in heterosis breeding [dissertation]. Ludhiana, India: Punjab Agricultural University; 2017.

34. Nsabiyera V, Ochwo-Ssemakula M, Sseruwagi P. Field performance and quality traits of hot pepper genotypes in Uganda. Afr Crop Sci J. 2012;20:123-39.

35. Shrestha SL, Luitel BP, Kang WH. Heterosis and heterobeltiosis studies in sweet pepper (Capsicum annuum L.). Hort Environ Biotechnol. 2011;52:278-83.

36. Matsunaga H, Yanokuchia Y, Motokib S, Okamotoc K, Murayama S. Breeding 'Sweet Pepper Parental Line Nou1 ' with genic male sterility. Hort Res (Japan). 2007;6:177-78.

37. Sood S, Kumar N. Heterosis for fruit yield and related horticultural traits in bell pepper. Int J Veg Sci. 2010;16:36173.

38. Nascimento NFF, Rêgo ER, Nascimento MF, Bruckner CH, Finger FL, Rêgo MM. Combining ability for yield and fruit quality in the pepper Capsicum annuum. Genet Mol Res. 2014;13:3237-49.

39. Klieber A. Paprika spice production. In: Dris R, Niskanen R, Jain SM, editors. Crop management and postharvest handling of horticultural products, Volume I- Quality management. Enfield, NH, USA: Science Publishers Inc.; 2001. p. 133-56.

40. Lannes SD, Finger FL, Schuelter AR, Casali VWD. Growth and quality of Brazilian accessions of Capsicum chinense fruits. Sci Hortic. 2007;112:266-70.

41. Gözen V, Özalp R, Çelik I. Evaluation of heterosis on yield and fruit number of hybrid bell pepper (Capsicum annuum L.) in unheated greenhouse condition. Acta Hortic. 2020;1282: 75-82.

42. Aditika, Kanwar HS, Priyanka, Singh S, Singh S. Heterotic potential, potence ratio, combining ability and genetic control of quality and yield traits in bell pepper under net-house conditions of NW Himalayas. Agric Res. 2020;9:526-35.

43. Sharma VK, Punetha S, Sharma BB. Heterosis studies for earliness, fruit yield and yield attributing traits in bell pepper. Afr J Agric Res. 2013;8:4088-98.

44. Rao PG, Reddy KM, Naresh P, Chalapathi V. Heterosis in bell pepper (Capsicum annuum L.) for yield and yield attributing traits. Bangladesh J Bot. 2017;46:745-50.

45. Aiswarya CS, Vijeth S, Sreelathakumary I, Kaushik P. Diallel analysis of chilli pepper (Capsicum annuum L.) genotypes for morphological and fruit biochemical traits. Plants. 2020; 9:1. https://doi.org/10.3390/plants9010001

46. Ben-Chaim A, Paran I. Genetic analysis of quantitative traits in pepper (Capsicum annuum). J Am Soc Hortic Sci. 2000;125:66-70.

$$
\begin{aligned}
& \text { (C) (1) (5) } 2021 \text { by the authors. Submitted for possible open access publication under the terms and } \\
& \text { conditions of the Creative Commons Attribution (CC BY NC) license } \\
& \text { (https://creativecommons.org/licenses/by-nc/4.0/). }
\end{aligned}
$$

